Images in...

\title{
A child with delayed milestones and interesting findings on MR
}

\author{
Sanwar Agrawal \\ Ekta Institute of Child Health, Raipur, India
}

Correspondence to Sanwar Agrawal, drsanwar50@gmail.com

\section{DESCRIPTION}

A 13-month-old male child born of a second degree consanguineous marriage presented with delayed milestones; notably, he was not able to pull to sit or stand and he was swaying from side to side when pulled to sit.

$\mathrm{He}$ had bilateral post-axial polydactyly ${ }^{1}$ (figure 1). He never experienced any respiratory difficulty and there was no history of apnoeic episodes.

The central nervous system examination was remarkable for generalised hypotonia and gross developmental delay. The child was not able to pull to sit or stand. On attempted sitting he showed truncal ataxia and on approaching an object showed premature grasp and tremulousness. There was no nystagmus. He had started speaking non-specific 'ma' and 'pa'.

Ocular fundi were normal.

Sonography of the abdomen did not show any renal cyst.
MRI of the brain showed features commonly associated with Joubert syndrome and Joubert syndrome related disorders $^{2}$ (figure 2), for example:

dilatation of the fourth ventricle with bat-wing shaped appearanceelongation and stretching of the superior cerebellar peduncles-the molar tooth appearanceabsence of the cerebellar vermis.

The distinctive radiological feature of Joubert syndrome in MRI is molar tooth sign, which has been reported in about $85 \%$ patients. This results from dysplastic and thick superior cerebellar peduncles, and deep and wide interpeduncular cisterns. The bat-wing appearance emanates from the dilated fourth ventricle and an anteriorly convex floor. The other sign described, is a buttock sign, because the hypoplasia of vermis causes the cerebellar hemisphere to come closer. Hypoplasia of corpus callosum is also described. $^{3}$

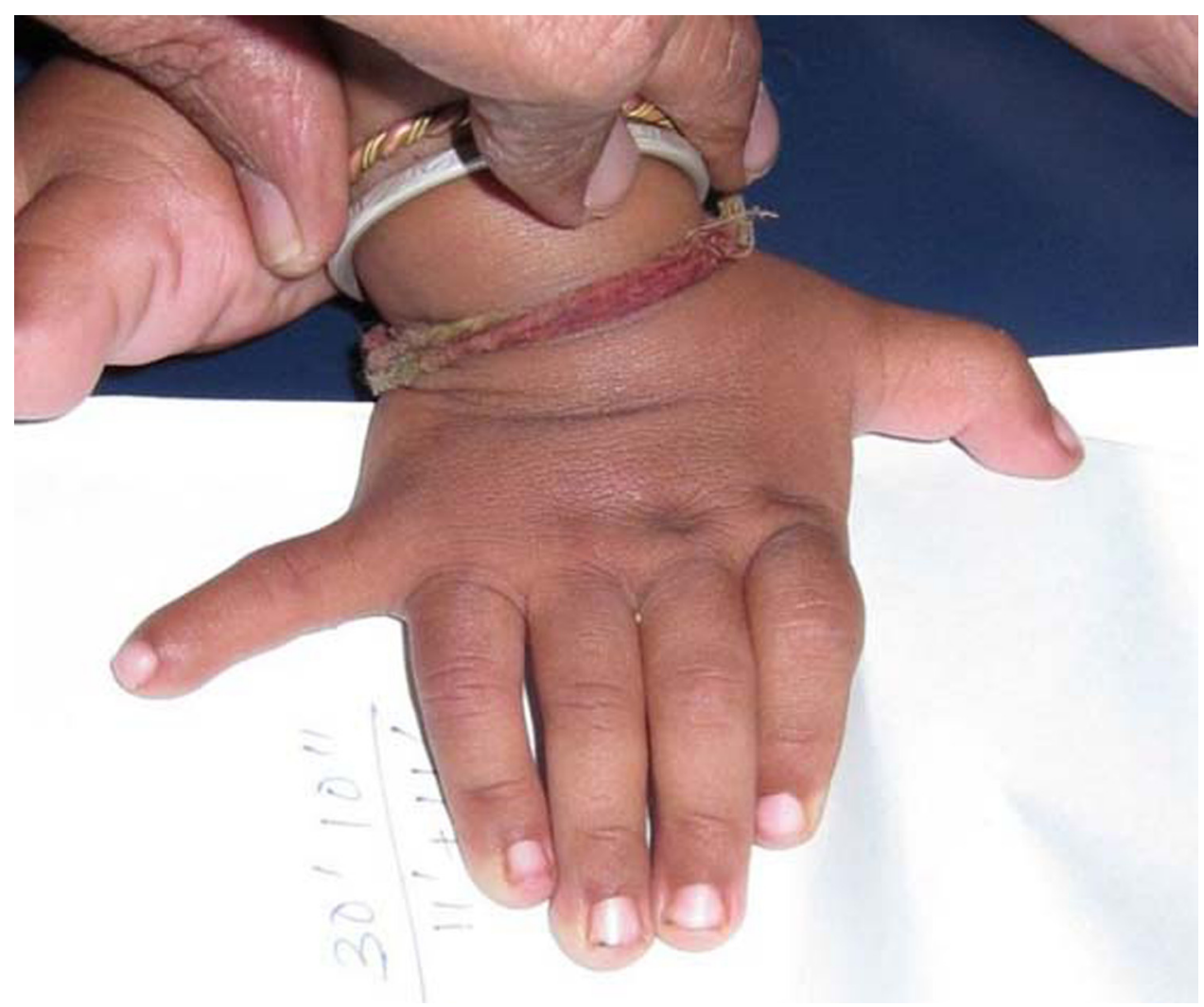

Figure 1 Post-axial polydactyly. 


\section{BMJ Case Reports}

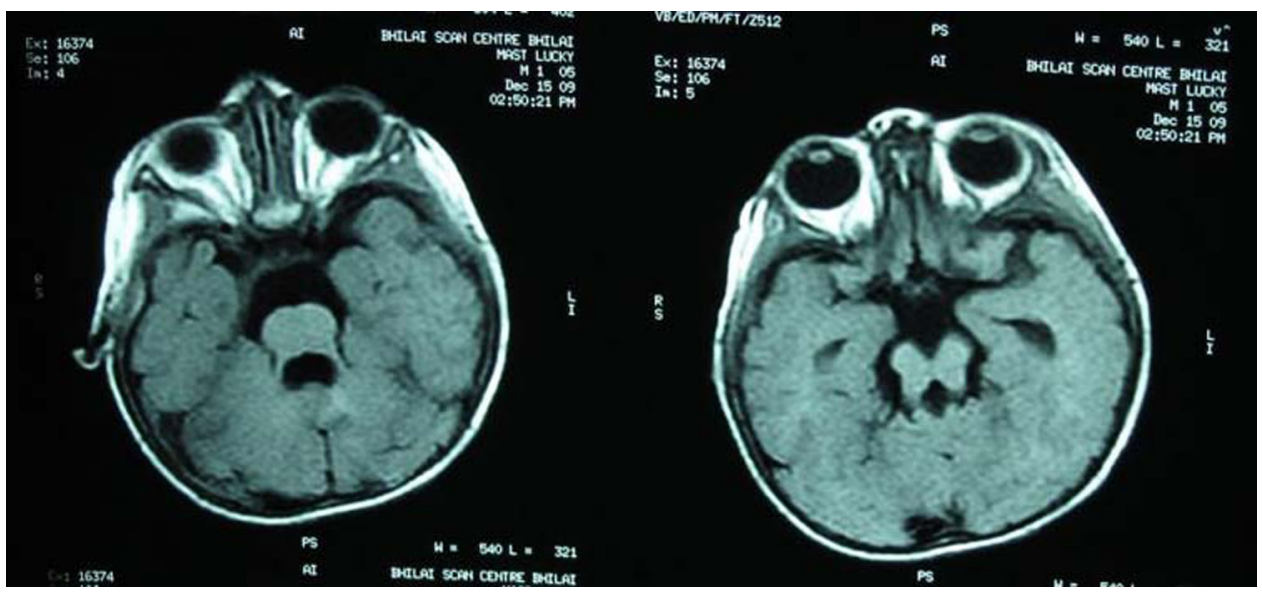

Figure 2 MRI brain showing molar tooth appearance, bat-wing dilatation of the 4th ventricle and absence of cerebellar vermis.

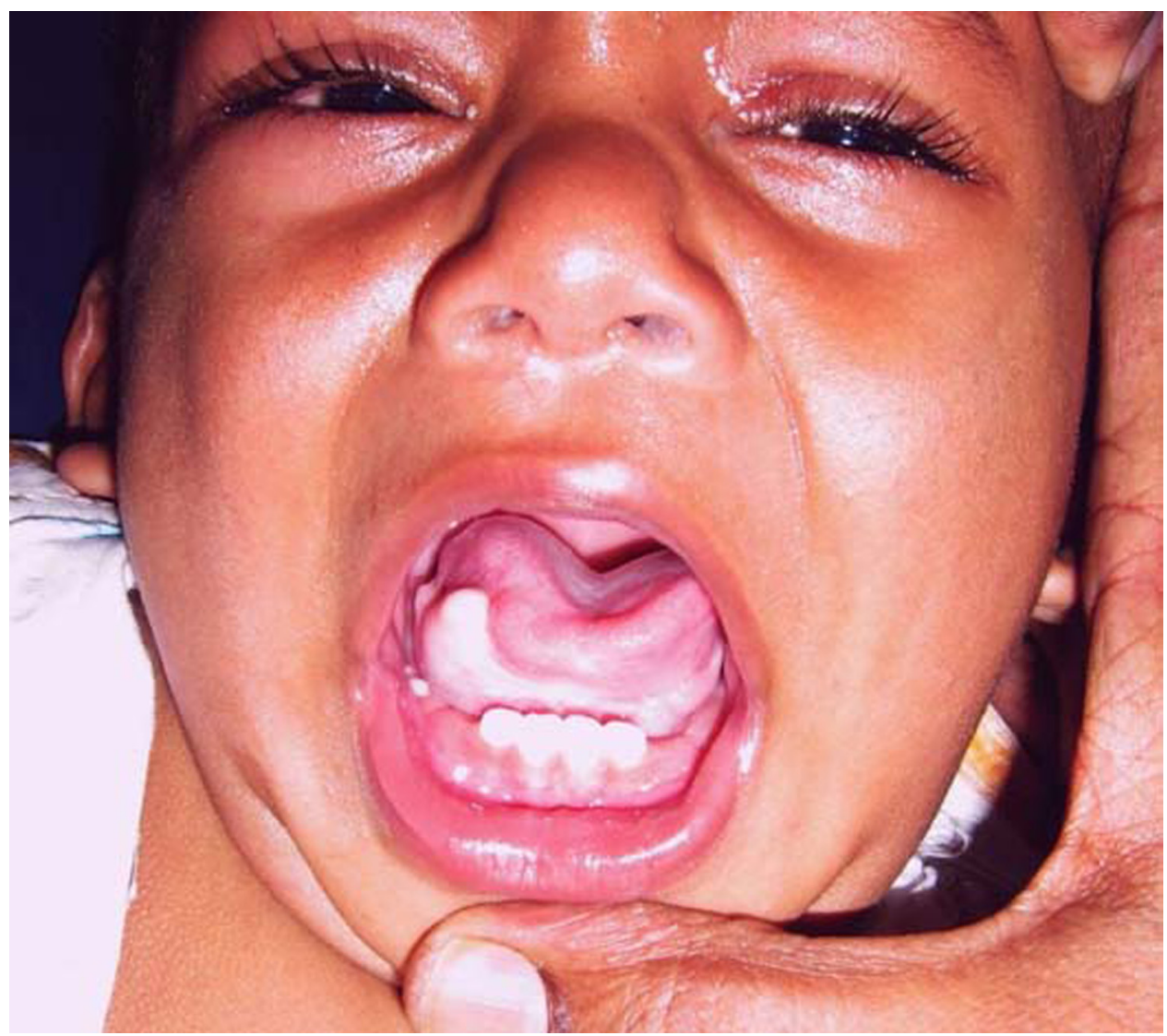

Figure 3 Extra strand of tissue below tongue (oral frenulae).

Moreover, other syndromes with posterior-fossa malformations, including Dekaban-Arima, Senior-Löken and cerebellar vermis hypoplasia/aplasia, oligophrenia, ataxia, coloboma and hepatic fibrosis, frequently lead to diagnostic dilemmas. However, the presence of the same clinical and neuroradiological features is shared by at least eight distincts conditions under the term Joubert syndrome related disorders (JSRD). Presence of ataxia and findings on neuroimaging should lead to suspicion of Joubert syndrome and related disorders, which can be confirmed and typified by genetic testing - this was refused by the family.
The association of primary criteria of Joubert syndrome and polydactyly may be suggestive of JSRD such as orofacial-digital VI syndrome (Varadi-Papp syndrome). This refers to one type of oro-facial disorder. This child also showed extra strands of tissue below the tongue-the oral frenulae (figure 3). However, this case did not show other orofacial features like cleft palate, or abnormalities of tongue, teeth and other facial dysmorphism.

Oro-facial digital syndrome II (Mohr syndrome), an autosomal recessive disorder, has been described with oral anomalies (Bifid tongue, tongue nodules, enlarged mouth 


\section{BMJ Case Reports}

frenuli, multiple frenuli) and digital anomalies (syndactyly, post axial polydactyly, hallucal abnormalities). Cases of Mohr syndrome with cerebellar atrophy and other cerebellar anomalies are described. ${ }^{4}$ The overlap between Joubert syndrome and oro-facial-digital syndrome has also been described by Egger. ${ }^{5}$

Our case presented with developmental delay, cerebellar signs, MRI having features associated with Joubert syndrome and some oro-facial-digital anomalies. Absence of respiratory symptoms makes this a very interesting case.

\section{REFERENCES}

1. Maria BL, Boltshauser E, Palmer SC, et al. Clinical features and revised diagnostic criteria in Joubert syndrome. J Child Neurol 1999;14:583-90; discussion 590-1.

2. Shen WC, Shian WJ, Chen CC, et al. MRI of Joubert's syndrome. Eur J Radiol 1994;18:30-3.

3. Alorainy IA, Sabir S, Seidahmed MZ, et al. Brain stem and cerebellar findings in Joubert syndrome. J Comput Assist Tomogr 2006;30:116-21.

4. Annerén G, Gustavson KH, Jòzwiak S, et al. Abnormalities of the cerebellum in oro-facio-digital syndrome II (Mohr syndrome). Clin Genet 1990;38:69-73.

5. Egger J, Bellman MH, Ross EM, et al. Joubert-Boltshauser syndrome with polydactyly in siblings. J Neurol Neurosurg Psychiatry 1982;45:737-739.

\section{Competing interests None.}

Patient consent Obtained.

This pdf has been created automatically from the final edited text and images.

Copyright 2010 BMJ Publishing Group. All rights reserved. For permission to reuse any of this content visit http://group.bmj.com/group/rights-licensing/permissions.

BMJ Case Report Fellows may re-use this article for personal use and teaching without any further permission.

Please cite this article as follows (you will need to access the article online to obtain the date of publication).

Agrawal S. A child with delayed milestones and interesting findings on MR. BMJ Case Reports 2010;10.1136/bcr.05.2010.3037, date of publication

Become a Fellow of BMJ Case Reports today and you can:

- Submit as many cases as you like

- Enjoy fast sympathetic peer review and rapid publication of accepted articles

Access all the published articles

- Re-use any of the published material for personal use and teaching without further permission

For information on Institutional Fellowships contact consortiasales@bmjgroup.com

Visit casereports.bmj.com for more articles like this and to become a Fellow 